Journal of the Scholarship of Teaching and Learning, Vol. 20, No. 2, October 2020, pp. 1-14.

doi: 10.14434/josotl.v20i2.27446

\title{
Who Improves Most? The Differences in First-Year Students' Learning Attitudes and Behaviors Measured by College Success Factor Index
}

\author{
Masha Krsmanovic \\ University of Central Florida \\ Thomas. D. Cox \\ University of Central Florida \\ Jamil D. Johnson \\ University of Central Florida
}

\begin{abstract}
Utilizing a pretest-posttest quasi-experimental research design, this study investigated the impacts of the participation in a First-Year Seminar (FYS) course on student learning attitudes and behaviors. Using the sample of 1,231 freshmen students in a large, public, research university in the Southeast, the study examined if FYS participation promoted students learning attitudes and behaviors in the following ten areas: responsibility, competition, task-planning, expectation, wellness, time-management, college involvement, family involvement, precision, and persistence. Additionally, the study tested for the differences in changes of students learning attitudes and behaviors among five student populations enrolled in the seminar: first-time in college, summer bridge, international, out-ofstate, and teacher pre-professionals. Hotelling's $T^{2}$ test revealed statistically significant differences in learning attitudes and behaviors between pre and posttests for each of the 10 measured factors, while a two-way mixed design MANOV A indicated that changes in students' learning attitudes and behaviors were not significantly different for any of the factors depending on the subgroup. The lack of between-group differences demonstrated that the FYS course participation was equally beneficial for students from all populations examined in the study.
\end{abstract}

Keywords: learning attitudes and behaviors, student success, first-year seminar

\section{Introduction}

Due to the growing student diversity on American college campuses, it is safe to say that a traditional undergraduate is a concept of the past. Modern college students, most frequently referred to as Generation Y, are characterized as having first arrived on campuses around 2000 and remaining enrolled beyond 2020 (Rickes, 2009). Over the past decade, research has identified a multitude of ways in which modern learners reshaped higher education campus spaces (Rickes, 2009) and university policies (Oblinger, 2003). However, the most comprehensive impacts of ever-changing student characteristics are recorded in the diversification of learning and teaching strategies across all disciplines (Sternberg, 2012).

Consequently, traditional teaching methods and learning strategies are giving way to innovative approaches that would better help higher education institutions (HEIs) meet the needs and expectations of their incoming student population. For example, past empirical evidence provides abundant support for the assertion that, compared to previous generations of college students, modern undergraduates embrace a plethora of learning attitudes that can only be supported through innovative teaching strategies and learning environments (Pardue \& Morgan, 2008; Shaw \& Fairhurst, 2008; Sternberg, 2012). 
Along with fostering these innovative practices, HEIs are becoming increasingly engaged in establishing academic programs that would specifically promote the learning of first-year students and, consequently, their academic transition and success. Additionally, the national efforts directed towards supporting freshman learning and ensuring their retention to the sophomore year have aroused considerable scholarly attention. Up to this day, the research in the domain of first-year students has expanded to include a wide variety of factors that affect their academic trajectories, as well as a multitude of curricular interventions designed to accelerate the knowledge acquisition of this student group.

Among the educational interventions of this type, first-year seminar (FYS) courses remain one of the most frequently implemented tools. According to 2013 survey of FYS courses, almost $90 \%$ of higher education institutions in the United States reported offering some type of this class, with more than $50 \%$ of institutions designating the course as a general education requirement. In terms of seminar types, more than $40 \%$ of institutions implemented their FYS course as an extended orientation and nearly similar percentage offered a study skills class format (NRC, 2013). Even though empirical contributions have continuously been made in the domain of FYS learning outcomes, the efforts in this area remain limited by one important characteristic. Namely, the evidence on the seminar impacts has predominantly been produced collectively for all course participants in a single research setting and among homogenous group of First-Time in College (FTIC) students, thus offering a limited understanding of individual or group learning differences.

In an attempt to overcome such limitation, this study examined the following two research questions:

1. Does participation in the first-year seminar (FYS) course change students learning attitudes and behaviors for any of the 10 factors measured by the College Success Factor Index (CSFI): Responsibility, Competition, Task-planning, Expectation, Wellness, Time-management, College Involvement, Family Involvement, Precision, and Persistence?

2. Are there any differences in changes of students learning attitudes and behaviors for any of the 10 examined factors between the five special student populations: first-time in college, summer bridge, international, out-of-state, and teacher pre-professionals?

\section{Literature Review}

First-Year Seminars and Students' Learning Attitudes

The role of FYS courses in promoting students' learning behaviors records a long history in American higher education. A more recent scholarly evidence supports the overarching premise that seminar participation can positively influence students' learning in several important ways. The majority of findings were recorded in the domain of the development of self-regulated learning skills, primarily in terms of planning, monitoring, and evaluating one's learning (Cambridge-Williams, Winsler, Kitsantas \& Bernard, 2013; Hoops, Burridge, \& Wolters, 2015; Hoops, \& Artrip, 2016).

Additionally, the course participation was found to promote first-year students' active learning behaviors (Andrade, 2009; Mills, 2010), as well positive academic practices such as class attendance and participation or establishing relationships with faculty (Bender, 2001; Kuh, Kinzie, Buckley, Bridges \& Hayek, 2006). Moreover, the literature has documented that the enrollment in FYS courses can deepen students' motivation to learn (Hoops, Burridge, \& Wolters, 2015; Hoops \& Artrip, 2016; Jessup-Anger, 2011) and have a positive impact on their life-long learning orientations (Padgett, Keup \& Pascarella, 2013).

Journal of the Scholarship of Teaching and Learning, Vol. 20, No. 2, October 2020. josotl.indiana.edu 
However, the major gap in the research in this area is reflected in the historical practice of examining the effectiveness of FYS courses among the homogenous sample of FTIC students, thus reducing the opportunity for exploring the course impacts among diverse student groups. Very few studies investigated the course potency for improving the learning attitudes and behaviors of diverse student populations. Thus, only a few studies produced the empirical evidence on the role of FYS courses in improving academic performance and success of non-traditional student populations such as international students (Andrade, 2006), African American students (Fidler \& Godwin, 1994), and Latino/a student (Barnes, 2012).

The need for the research in this direction is further emphasized by work of That and Must (2013) who explored the differences in learning attitudes among students from 55 countries. In addition to the expected contrasts in educational systems of students' home counties, the findings also reflected the differences in learning attitudes based on one's cultural backgrounds, as well as the effects of these differences on students' academic progress. Still, the comparison of the impacts of a specific curricular intervention on learning attitudes among students from diverse populations are still missing from the literature.

\section{College Success Factor Index (CSFI)}

Of particular importance for this study is the scholarly evidence pertaining to the FYS course impacts on the 10 learning attitudes and behaviors measured by the College Success Factor Index (CSFI): Responsibility, Competition, Task-planning, Expectations, Family Involvement, College Involvement, Time-management, Wellness, Precision, and Persistence. Additionally, this study was further informed by the prior scholarship that documented the connection between students' development in any of the 10 CSFI areas and their overall academic success.

In an effort to improve student learning outcomes, the FYS program examined in this study introduced the College Success Factor Index (CSFI) assessment in summer 2013. The main purpose of the assessment was to measure students self-reported improvement of learning attitudes and behaviors for each of the 10 factors. Participants' perceptions of positive changes in their attitudes were used to identify the most effective practices of the course curriculum. Conversely, participants' perceptions of limited improvement for any of the 10 factors were utilized to place additional focus on the identified areas in the future curriculum planning.

Responsibility. For the purpose of CSFI assessment, Responsibility factor was defined as the level of responsibility or control a student has over their actions and the outcomes of these actions. The past research that explored the role of Responsibility factor in connection to college student learning documented that undergraduates with a high locus of control benefited from increased GPA, academic performance, and self-assurance (Drago, Rheinheimer, \& Detweiler, 2018). Similarly, students with an internal and changeable locus of control were found to perform better than their peers with an external and unchangeable locus of control (Stupinsky et al., 2007). However, literature simultaneously documented that modern learners tend to predominantly exhibit external locus of control, thus being significantly more inclined toward attributing their academic outcomes to factors beyond their influence (Twenge, Zhang, \& Im, 2004) As a result, the students with internal locus of control become less likely to take personal responsibility for their academic outcomes and take active initiative toward improvement (Shaw \& Fairhurst, 2008;

The relationship between participation in FYS courses and Responsibilities factors has not yet received much scholarly attention. The scarce literature evidence that exists documented that, for students on academic probation, the seminar participation was not effective in promoting their internal locus of control (Mellor, Brooks, Gray, \& Jordan, 2015).

Journal of the Scholarship of Teaching and Learning, Vol. 20, No. 2, October 2020. josotl.indiana.edu 
Competition. CSFI assessment defined Competition as students' need to compete in varied aspects of their personal, college, and career journeys. The benefits of being committed to one's goal have been well-supported in the research on students success. For example, students with high levels of commitment to academic goals not only performed better than their peers who were not as dedicated, but were also more likely to persist when encountering academic setbacks or failures (Turner \& Husman, 2008). In regards to the relationship between FYS courses and Competition factor, the literature review conducted for this study did not yield any empirical studies that specifically examined the potency of the seminar to foster this factor among the participants.

Task-planning. The factor of Task-planning postulates that a strong task orientation and a desire to complete a task are very important to college success. Scholarly evidence provides rich examples to support this premise. The importance of task-planning for first-year students has been corroborated by the finding that students who planned out their studying activities performed better academically (Krumrei-Mancuso, Newton, Kim, \& Wilcox, 2013). Furthermore, students who engaged in detailed and thorough planning by, for example, using elaborate to-do lists, were more likely to complete academic tasks ahead of schedule (Cavanaugh, Lamkin, \& Hu, 2012). With regard to the role of FYS in improving students' task-planning skills, Hoops and Artrip (2016) recorded that course enrollment can lead to the development of self-regulating skills, particularly in the domain of planning and monitoring one's academic tasks.

Expectations. Expectations factor presumes that successful students have clearly identified goals related to their areas of study and future careers. The literature exploring the role of this factor in college student success is abundant and extensive. After conducting an extensive review of 35 years of research on personal, academic, and career goal setting, Locke and Latham (2002) concluded that high goals were directly associated with high levels of effort and performance. Additionally, Reynolds and Baird (2011) established that, among the students who failed to fulfill their educational goals, the students who with initially higher expectations recorded lower levels of depression than their peers with lower expectations.

Similarly, the research on FYS courses attested to the positive relationship between goal setting and student success. For instance, students who completed the seminar strongly emphasized the importance of setting long- and short-term goals, continuously evaluating their goals, and understanding the interrelationship between goals and motivation (Hoops \& Artrip, 2016)

Family involvement. This factor indicates that family encouragement and participation in students' academic planning and decision-making are strong contributors to educational success. Examining the ways in which parental support can influence undergraduate students' attitudes toward college, Kranstuber, Carr, and Hosek (2012) established that this type of support could fulfill students' emotional needs during the transition stage and encourage them to apply their talents towards being academically successful. Specifically, the educational messages that parents provided to their children were positively associated with students' cognitive development, academic motivation, learner empowerment, and overall college satisfaction.

Even though a great body of research examined and affirmed the FYS course efficacy in fostering student peer involvement (Andrade, 2006; Keup, 2005) and the involvement of faculty in student academic planning (Keup \& Barefoot, 2005; Kuh et al., 2006) the connection between course participation and family involvement represents another deficiency of the literature in this domain.

College involvement. According to this factor, being involved in college activities, relating to faculty, and developing strong peer relationships are important contributors to student success and 
retention. Perennial scholarly contribution to this area was made by Astin's (1984) and his Theory of Student Involvement. The theory postulated that the amount of student learning and development in an educational institution is directly proportional to the extent of student involvement in that institution. Subsequent research confirmed this hypothesis by documenting that college involvement served as a strong predictor of students' perseverance and academic achievement (Strap \& Farr, 2010). Additionally, extensive and strong college networks were found to have a long-term positive impact on students' post-graduation careers in terms of increased chances for employment (Vilorio, 2011) and higher career satisfaction (Wolff \& Moser, 2009).

The research examining the relationship between FYS participation and college involvement is rich and multifold. Of the most interest for this study are the indications that seminar participation can lead to students' perceptions of the campus environment as more supportive (Mills, 2010), their increased use of campus resources services (Keup \& Barefoot, 2005; Kuh et al., 2006; Mills, 2010) and their reduced feelings of isolation from campus life (Keup, 2005).

Time-management As specified by the 'Time-management factor, students' ability to maximize the use of time and prioritize academic tasks affects their productivity and success. Numerous studies examined the relationship between time-management and undergraduate student success producing support for the claim that effective time-management practices result in higher academic performance and self-efficacy (Kitsantas, Winsler, \& Huie, 2008), as well as first-semester motivation and satisfaction (Thompson, Orr, Thompson, \& Grover, 2007).

The most evidence on the role of FYS courses in improving students' time-management skills has been produced in relation to the development of self-regulation skills (Hoops \& Artrip, 2016). In that regard, FYS participants revealed that, upon completing the course, they began perceiving time management as one of the most critical factors in becoming effective college students and started attributing their past failures to poor time management and procrastination.

Wellness. According to the Wellness factor, managing stress and developing proper nutrition and sleep patterns positively impact student outcomes. The literature supported this premise by illustrating that one's ability to maintain stress at a moderate level can lead to improved academic performance (Rath, 2008). Similarly, regular physical activity, healthy nutrition, and balanced sleep patterns were all positively associated with increased academic performance. The few studies that investigated the association between FYS courses and Wellness factor revealed that participation in a student success class can lead to improved knowledge of wellness (Bell, 2012) and reduced academic stress (Everett, 2013).

Precision. The Precision factor refers to the persistence in completing academic tasks and being detail-oriented. The empirical findings in this area revealed that undergraduates who failed to dedicate their full attention and effort to one task experienced a range of negative academic outcomes. Thus, in-class multitasking and lack of precision were found to be detrimental to students' academic performance and their semester GPA (Junco, 2012). Regarding the research on FYS courses, an intangible connection between the seminar and Precision factor can be proposed given the evidence that class participation can lead to improved self-regulation skills (Hoops \& Artrip, 2016; Hoops, Burridge, \& Wolters, 2015). Still, due to the lack of studies that specifically addressed the relationship between seminar programs and students' precision a direct relationship between the two cannot yet be claimed.

Persistence. The factor of Persistence refers to students' ability to develop a sense of selfencouragement, commitment, and personal urgency. Many theoretical models that examined the 
factors associated with persistence identified self-efficacy as one of the most powerful contributors to students' decision to persist academically. Self-efficacy, or one's belief in their ability to successfully complete a task (Bandura, 1997), was also found to have a strong effect on students' resilience or their ability to bounce back and persist in spite of difficulties or negative experiences (Komarraju \& Nadler, 2013).

The constructs of student persistence, commitment, self-encouragement, resilience, and selfefficacy constitute the most frequently examined areas of FYS learning outcomes. In addition to seminar potency to promote students' retention rates (Cambridge-Williams et al., 2013; Miller \& Lesik, 2014; Tuckman \& Kennedy, 2011), class enrollment was also associated with improved graduation rates (Lang, 2007; McGrath \& Burd, 2012; Miller \& Lesik, 2014; Tuckman \& Kennedy, 2011). Moreover, the course participation was found to foster the academic self-efficacy of both FTIC students (Cambridge-Williams et al., 2013) and students on academic probation (Mellor, Brooks, Gray, \& Jordan, 2015).

The literature examined in this section provides rich evidence on the relationship between the 10 CSFI factors and student academic outcomes, learning attitudes, and overall college transition. At the same time, the presented findings confirmed the centrality of the First-Year Seminar (FYS) courses in fostering student development across all 10 factors. In an attempt to advance the research in both domains, this study explored the effects of a FYS seminar course on all 10 factors simultaneously. Additionally, the scholarly limitations identified in this review were addressed by examining the differences in learning attitudes and behaviors among diverse student populations.

\section{Method}

\section{Background and Setting}

This study was conducted at a large public research institution in the Southeastern region of the United States. In the academic year 2016-2017, when the CFSI assessment was administered, the institution enrolled 6,901 first-year students. The overall student population was characterized by a highly diverse student body consisting of 50.9\% White, 23.8\% Hispanic/Latino, 11.1\% African American, 6.1\% Asian, and 3.6\% Multiracial students.

The First-Year Seminar (FYS) course examined in this study is housed within two institutional units: First-Year Experience (FYE) and the College of Education. The course is classified as a 3-credit hour academic-themed seminar with a standardized curriculum across all class sections. In the academic year 2016-2017, the total of 1362 first-year students enrolled in the course, of which 414 in fall, 127 in spring, and 821 in summer.

Classified as an academic-themed seminar, the overarching objective of the course is the development of research-proven student life skills and increased application of student success strategies. The course content is conceptually framed in student development theories, mainly the theories of cognitive, psychosocial, social, and ethical development.

The course curriculum and learning objectives are characterized by several important attributes. First, a substantial portion of the curriculum focuses on the application of research-proven student success strategies, mainly the development of skills and competencies in the areas of motivation, time management, studying, test-taking, academic writing, and undergraduate research. Additional emphasis is placed on students' academic and social integration through the engagement in high-impact practices and co-curricular learning experiences, mainly undergraduate research, internships, peer mentoring, registered student organizations, and student leadership programs. The third area of curricular focus is directed toward career exploration and career-readiness. The key

Journal of the Scholarship of Teaching and Learning, Vol. 20, No. 2, October 2020. josotl.indiana.edu 
objectives in this domain include familiarization with academic advising and career services, resume building, informational interviews, internships, volunteering, and service-learning.

Even though the seminar is offered as an elective to all incoming first-year students, special student populations are required to enroll. These populations include students from the summer bridge program, student-athletes, students on academic probation, international students, out-of-state students, and students from specific majors.

\section{Participants}

The initial sample for this study consisted of 1,640 first-year students who completed the CSFI preassessment in their FYS course during the academic year 2016-2017. Of these students, 1,231 completed the post-assessment. The approval from the institutional Review Board (IRB) was obtained for using the de-identified student responses to CSFI assessment for the purpose of this research. The number and percentage of students from each class section who completed the posttest are presented in Table 1.

Table 1: Study sample

\begin{tabular}{lll}
\hline Section & $\mathrm{N}$ & Percent \\
\hline First Time in College & 773 & 62.8 \\
Summer bridge & 351 & 28.6 \\
International & 36 & 2.9 \\
Out-of-state & 41 & 3.3 \\
Teacher pre-professionals & 30 & 2.4 \\
\hline
\end{tabular}

\section{Design}

For the first research question, the independent variable was the course participation in which the participants were measured before and after completing the seminar. Ten dependent variables measured the change in students learning attitudes and behaviors for each of the 10 examined factors: Responsibility, Competition, Task-planning, Expectations, Family Involvement, Time Management, Wellness, Precision, and Persistence.

For the second research question, five measures of independent variables were used, each representing one special student population: First-Time in College (FTIC), Summer Bridge, International, Out-of-State, and Teacher Pre-Professionals. The same dependent variable was used to measure the between-group differences in students learning attitudes and behaviors for the 10 examined factors.

\section{Instrument}

College Success Factor Index (CSFI). The purpose of College Success Factor Index (CSFI) assessment is to inform learners and instructors of students' individual strengths and weakness for each of the 10 measured factors. The assessment is designed to help identify the areas for improvement to be addressed by future curricular interventions.

In this study, students' learning attitudes and behavior were measured by administering CSFI pre and post-assessment to all students enrolled in the FYS course. Pre and posttests consisted of 100 Likert-type questions with 10 questions pertaining to each factor. Each question had five responses that ranged from "Strongly Agree" to "Strongly Disagree". The score for each of the 10 factors ranged 
from 10 (high success) to 50 (low success). Therefore, the lowest overall score was 100 and the highest possible score was 500. When interpreting the test scores, it is important to keep in mind that a high posttest score reflects a low improvement in learning attitudes and conversely, a low score reflects a high improvement for any of the examined factors.

\section{Procedure}

CSFI assessment was integrated into the course Learning Management System and administered to all students in the FYS courses as a class assignment. Pre-assessment was administered to all 1,640 participants in the first week of fall, spring, and summer semester. In the last week of each term, the post-assessment was administered only to 1,231 students who completed the pre-assessment.

\section{Results}

The first research question was tested by conducting a within-subject multivariate analysis of variance (MANOVA). Hotelling's $T^{2}$ test was used to measure the pre and post-test differences. Hotelling's $T^{2}$ test revealed statistically significant differences between pre and post-tests for each of the 10 factors: $T^{2}=.510, \mathrm{~F}(10,1212)=62.266, \mathrm{p}<.001, \eta^{2}=.338$.

Table 2 presents descriptive and inferential statistics, including means and standard deviations for pre and posttest scores for each of the 10 factors. Although there was a significant change between pretest and posttest for all 10 factors, the factors varied in the level of change. There were moderate effect sizes for six factors for which effect size values were close to .5 (Cohen, 1998): Competition, Task-planning, Wellness, College involvement, Precision, and Persistence.

Table 2: Descriptive and inferential statistics for pre and posttest

\begin{tabular}{lccccc}
\hline Factor & $M D$ & $S D$ & $t$ & $p$ & $d$ \\
\hline Responsibility & 1.31 & 3.60 & 12.76 & $<.001$ & .364 \\
\hline Competition & 2.32 & 4.45 & 18.34 & $<.001$ & .521 \\
\hline Task-planning & 1.89 & 4.11 & 16.10 & $<.001$ & .460 \\
\hline Expectations & 1.24 & 3.77 & 11.54 & $<.001$ & .329 \\
\hline Wellness & 2.76 & 4.75 & 20.39 & $<.001$ & .581 \\
\hline Time-management & 1.85 & 4.68 & 13.87 & $<.001$ & .395 \\
\hline College involvement & 2.26 & 4.41 & 17.97 & $<.001$ & .512 \\
\hline Family involvement & .91 & 3.81 & 8.34 & $<.001$ & .239 \\
\hline Precision & 2.28 & 4.51 & 17.77 & $<.001$ & .510 \\
\hline Persistence & 2.23 & 5.08 & 15.39 & $<.001$ & .439 \\
\hline
\end{tabular}

The second research question was tested by conducting a two-way mixed design MANOVA. As Box's $M$ test indicated the violation of the assumption of homogeneity of variance and covariance $(\mathrm{p}<.001)$ Pillai's Trace test was used. When looking at all 10 factors, multivariate tests indicate that changes in students' behaviors and attitudes were not significantly different for any of the factors depending on the subgroup $\left(F=4880, \mathrm{p}=.424, \eta^{2}=.008\right)$. 


\section{Discussion}

The findings of this study addressed several critical gaps in contemporary literature on both first-year student learning and First-Year Seminar courses. As a result, a number of implications and recommendations for institutional improvement emerge from its results, all of which can be applied to other institutions of similar sizes and types or to FYS courses with similar design and curriculum.

The most powerful finding of this study is reflected in the fact that course participants displayed a statistically significant improvement in academic attitudes and behaviors for all 10 factors. This finding corroborated the work of Cox and Lemon (2016) who recorded statistically significant pre and post-tests differences for FYS participants within the same institution. Even though this study was conducted five years later, on a different sample of participants, and under a redesigned curriculum, the findings were equally powerful.

Next, even though the synthesis of the literature supported the association between FYS participation and student improved attitudes for some of the CSFI factors, the results of this study identified the course effects for all 10 factors simultaneously. In that regard, the presented findings confirmed the past scholarly findings on the positive course impacts for the following six factors: Task-planning (Hoops \& Artrip, 2016), Expectations (Hoops \& Artrip, 2016), Campus involvement (Mills, 2010), Time-management (Hoops \& Artrip, 2016), Wellness (Bell, 2012; Everett, 2013) and Persistence (Tuckman \& Kennedy, 2011).

At the same time, the results of this study challenged the findings of Mellor et al., (2015) who found no effects of the seminar in promoting the Responsibility factor or internal locus of control for students on academic probation. For the participants in this study, the course was beneficial for improving the level of control they had over their academic actions and outcomes. Moreover, the improvement in attitudes and behaviors toward the Responsibility factor was recorded for all participants in this study, including the students with low levels of academic preparedness in summerbridge class sections.

For the remaining three factors - Competition, Family involvement, and Precision, the findings of this research constitute a distinctive contribution to the field. As the synthesis of the literature presented in this paper revealed, the relationship between these three factors and FYS participation has not yet received a thorough scholarly investigation. Thus, this study represents a focal starting point for overcoming such deficiency in the research on FYS courses.

Next, this study provided a ranked classification of FYS course impacts on students improvement in learning attitudes and behaviors. In that regard, the results indicated that the lowest improvement was recorded for the factor of Family involvement $(M D=.91, S D=3.81, d=.239)$. This finding becomes particularly relevant in the context of the contemporary scholarship that identified parental support as a critical element in student transition to college, cognitive development, academic motivation, and college satisfaction (Kranstuber, Carr, \& Hosek, 2012). In that regard, the results of this research indicate that the FYS program needs to be further advanced by placing an additional emphasis on this factor in future curriculum planning. Specifically, due to the low improvement recorded in this domain, additional strategies need to be developed to increase the participation of family members in assisting first-year students with goal-setting, career-planning, and decision-making.

On the other hand, this study identified the factor of Wellness as the area of greatest improvement in students' attitudes and behaviors $(M D=2.76, S D=4.75, d=.581)$. Despite the variations in institutional settings, student populations, and FYS designs, these results remained consistent with the findings that FYS participation can improve participants' knowledge of wellness (Bell, 2012) and alleviate their stress (Everett, 2013).

Journal of the Scholarship of Teaching and Learning, Vol. 20, No. 2, October 2020. josotl.indiana.edu 
Another distinctive discovery of this study is that the improvement in students' learning attitudes and behaviors did not differ for any of the 10 factors depending on the student population. As one of the goals of this study was to assess the course effectiveness on different student populations, the lack of between-group differences indicated that FYS participation was equally beneficial for students from all populations: first-time in college, summer bridge, international, outof-state, and teacher pre-professionals. These results contribute to the literature in several important ways.

First, the positive course impacts on diverse student groups identified in this study advanced the scarce and not so recent studies that identified FYS as beneficial for the retention of AfricanAmerican students (Fidler \& Godwin, 1994), adjustment of international students (Andrade, 2006), and persistence of Latino/a students (Barnes, 2012). Advancing this knowledge further, the displayed findings indicated that, for international students enrolled in the seminar, participation promoted the improvement in learning attitudes and behaviors for all 10 factors critical for their academic success. At the same time, this research documented the seminar benefits for two student populations that have not yet been examined in the scholarship on FYS courses - out-of-state students and teacher pre-professionals. Thus, the findings indicate that institutions looking to support the development of students from these groups can effectively utilize FYS courses for attaining that goal.

The consistency of positive impacts of the seminar on diverse student groups recorded in this study is particularly relevant knowing that the majority of HEIs offer at least one special section of the FYS course (NRC, 2013). Therefore, the identified lack of between-group differences in course effects is especially pertinent to all FYS programs hosting special student populations as it informs them that the learning attitudes of diverse students can be addressed with a single intervention. Similarly, those colleges and universities that have not yet introduced FYS courses can apply these findings to consider implementing the seminar for both FTIC students and diverse student groups.

\section{Limitations and Future Research}

This research is characterized by several limitations all of which offer opportunities for further research. First, this study was conducted at a single institutional setting of a particular size and type. Therefore, additional research is needed to test these findings across different institutional settings. Expanding this research in a way that would encompass a multi-institutional design would offer a possibility for examining if the course effects on any of the 10 factors are moderated by institutional setting. The future research in this direction would also increase the diversity of student sample in terms of race, age, levels of academic preparedness, and academic majors. This approach, in turn, would offer additional insights into the levels of course effects among the student populations not included in this study.

Next, the data for this study were collected during one academic year. As the FYS program is assessed every year, curricular improvements are continuously implemented. Therefore, replicating this study over the course of another academic year and under a redesigned curriculum may yield different findings.

Third, this research examined the effects of one type of FYS class - academic-themed course with a uniform curriculum across all sections. As approximately $40 \%$ of American colleges and universities offer this type of a FYS course (NRC, 2012), additional investigation is needed to identify the benefits of other course types on the 10 examined factors. The research in this direction should first be directed towards examining the second most prevalent FYS course - extended-orientation seminar. Additional focus can be expanded to other common types of FYS courses, such as preprofessional or discipline related seminars.

Journal of the Scholarship of Teaching and Learning, Vol. 20, No. 2, October 2020. josotl.indiana.edu 
Another limitation of this research emerged from the quantitative research design. Even though the research method employed in this study allowed for the empirical assessment the course effects on student self-perceived improvement across all 10 factors, additional qualitative studies are needed to elicit further insights into student's perceptions of their individual development and the course effects. More specifically, a qualitative study would allow participants to share their experiences with the course, elaborate on their perceptions regarding its effectiveness, and provide recommendations for improvement.

\section{Conclusion}

This study yielded a number of critical implications for higher education professionals aiming to support the development of their diverse first-year students in the following 10 areas: Responsibility, Competition, Task-planning, Expectations, Family Involvement, College Involvement, Timemanagement, Wellness, Precision, and Persistence. At the same time, by advancing the existing research on FYS courses, this study investigated the seminar effectiveness on five student populations simultaneously: first-time in college, summer bridge, international, out-of-state, and teacher preprofessionals. As such, this research represents a rare contribution to the field by examining the between-group differences in students' educational attitudes and behaviors among special student populations. As a result, a foundation was laid for producing a number of innovative recommendations for all institutions currently offering or planning to introduce FYS programs.

As already stated, the most significant change brought upon the higher education by Generation Y is reflected in the plethora of students' learning attitudes and behaviors that can only be supported through innovative pedagogies and supportive environments (Pardue \& Morgan, 2008; Shaw \& Fairhurst, 2008; Sternberg, 2012). Therefore, the overarching recommendation of this study is that only by continuously re-examining their educational practices and making necessary improvements, can HEIs successfully meet the educational needs of their incoming learners. In that regard, this study has made a critical step in the important direction of assessing one educational intervention, a First-Year Seminar course, for the purpose of making data-driven decisions in the future curricular planning.

\section{References}

Andrade, M. S. (2006). A first-year seminar for international students. Journal of the First-Year Experience \& Student in Transition, 18(1), 85-103. Retrieved from https://eric.ed.gov/?id=EJ798184

Andrade, M. S. (2009). The value of a first-year seminar: international students' insights in retrospect. Journal of College Student Retention: Research, Theory \& Practice, 10(4), 483-506. Retrieved from https:// eric.ed.gov/?id=EJ832979

Astin, A. W. (1984). Student involvement: A developmental theory for higher education. Journal of College Student Personnel, 25(4), 297-308. Retrieved from https://eric.ed.gov/?id=EJ309521

Bandura, A. (1997). Self-efficacy and health behavior. In A. Baum, S. Newman, J. Wienman, R. West, \& C. McManus (Eds.), Cambridge handbook of psychology, health and medicine (pp. 160-162). Cambridge: Cambridge University Press

Barnes, J. (2012). The first-year experience impact on student success in developmental education. Journal of Applied Research in the Community College, 20(1), 27-35. Retrieved from https://eric.ed.gov/?id=ED563392

Bell, J. B. (2012). Assessing the effectiveness of an adventure-based first-year experience class. Journal of College Student Development, 53(2), 347-255. DOI:10.1353/csd.2012.0031

Journal of the Scholarship of Teaching and Learning, Vol. 20, No. 2, October 2020. josotl.indiana.edu 
Bender, D. S. (2001). Effects of study skills programs on the academic behavior of college students. Journal of College Reading and Learning, 31(2), 209-216. DOI: 10.1080/10790195.2001.10850116

Cambridge-Williams, T., Winsler, A., Kitsantas, A. \& Bernard, E. (2013). University 100 orientation courses and living-learning communities boost academic retention and graduation via enhanced self-efficacy and self-regulated learning. Journal of College Student Retention: Research, Theory \& Practice, 15(2) 243-268. DOI: 10.2190/CS.15.2.f

Cavanaugh, T., Lamkin, M. L., \& Hu, H. H. (2012). Using a generalized checklist to improve student assignment submission times in an online course. Journal of Asynchronous Learning Networks, 16(4). Retrieved from https://eric.ed.gov/?id=EJ982680

Cohen, J. (1988). Statistical power analysis for the behavioral sciences ( $2^{\text {nd }}$ ed.). Hillsdale, NJ: Lawrence Erlbaum Associates.

Cox, T. D., \& Lemon, M. (2016). A Curricular intervention for teaching and learning: Measurement of gains of first-year college student learning. Journal of the Scholarship of Teaching and Learning, 16(3), 1-10. Retrieved from https:// files.eric.ed.gov/fulltext/EJ1104870.pdf

Drago, A., Rheinheimer, D. C., \& Detweiler, T. N. (2018). Effects of locus of control, academic selfefficacy, and tutoring on academic performance. Journal of College Student Retention: Research, Theory \& Practice, 19(4) 433-451. DOI: 10.1177/1521025116645602

Everett, M. C. (2013). Reflective journal writing and the first-year experience. International Journal of Teaching and Learning in Higher Education, 25(2), 213-222. Retrieved from https://eric.ed.gov/?id=EJ1016545

Fidler, P. P., \& Godwin, M. A. (1994). Retaining African-American students through the freshman seminar. Journal of Developmental Education, 17(3), 34-40. Retrieved from https: / / eric.ed.gov/?id=EJ479880

Hoops, L. D. \& Artrip, A. (2016). College student success course takers' perceptions of college student effectiveness. Learning Assistance Review, 21(2), 55-67. Retrieved from https://eric.ed.gov/?id=EJ1114471

Hoops, L. D., Yu, S. L., Burridge, A. B., \& Wolters, A. C. (2015). Impact of a student success course on undergraduate academic outcomes. Journal of College Reading and Learning, 45(2), 123-146, DOI: $10.1080 / 10790195.2015 .1032041$

Jessup-Anger, J. E. (2011). What's the point? An exploration of students' motivation to learn in a first-year seminar. The Journal of General Education, 60(2), 101-116. Retrieved from www.jstor.org/stable/10.5325/igeneeduc.60.2.0101

Junco, R. (2012). In-class multitasking and academic performance. Computers in Human Behavior, 28, 2236-2243. DOI: 10.1016/j.chb.2012.06.031

Keup, J. R. (2005). The impact of curricular interventions on intended second-year re-enrollment. Journal of College Student Retention: Research, Theory \& Practice, 7(1-2), 61-89. DOI: 10.2190/2DCU-KABY-WVQH-2F8J

Keup, J. R., \& Barefoot, B. O. (2005). Learning how to be a successful student: Exploring the impact of first-year seminars on student outcomes. Journal of the First-Year Experience \& Students in Transition, 17(1), 11-47. Retrieved from https://eric.ed.gov/?id=EJ795799

Kitsantas, A., Winsler, A., \& Huie, F. (2008). Self-regulation and ability predictors of academic success during college: A predictive validity study. Journal of Advanced Academics, 20(1), 42-68. Retrieved from https://eric.ed.gov/?id=EJ835868

Komarajju, M., \& Nadler, D. (2013). Self-efficacy and academic achievement: Why do implicit beliefs, goals, and effort regulation matter? Learning and Individual Differences, 25, 67-72, DOI: 10.1016/j.lindif.2013.01.005

Journal of the Scholarship of Teaching and Learning, Vol. 20, No. 2, October 2020. josotl.indiana.edu 
Kranstuber, H., Carr, K., \& Hosek, A. M. (2012). "If you can dream it, you can achieve it." Parent memorable messages as indicators of college student success. Communication Education, 61(1), 44-66, DOI: 10.1080/03634523.2011.620617

Krumrei-Mancuso, E. J., Newton, F. B., Kim, E., \& Wilcox, D. (2013). Psychosocial factors predicting first-year college student success. Journal of College Student Development, 54(3), 247266. DOI: https://doi.org/10.1353/csd.2013.0034

Kuh, G.D., Kinzie, J., Buckley, J. A., Bridges, B. K., \& Hayek, J. C. (2006). What matters to student success: $A$ review of the literature. NCES Report. https://nces.ed.gov/npec/pdf/kuh_team_report.pdf

Lang, D. J. (2007). The impact of first-year experience course on the academic performance, persistence, and graduation rates of first-semester college students at a public research university. Journal of the First-Year Experience \& Students in Transition, 19(7), 9-25. Retrieved from http://eric.ed.gov/?id=EJ798191

Locke, E. A. \& Latham, G. P. (2002). Building a practically useful theory of goal setting and task motivation: A 35-year Odyssey. American Psychologist, 57(9), 705-717. DOI: 10.1037//0003066X.57.9.705

McGrath, S. M., \& Burd, G. D. (2012). A success course for freshmen on academic probation: Persistence and graduation outcomes. NACADA Journal, 32(1), 43-52. Retrieved from https://eric.ed.gov/?id=EJ973057

Mellor, D. T., Brooks, W. R., Gray, S. A., \& Jordan, R. C. (2015). Troubled transitions into college and the effects of a small intervention course. Journal of College Student Retention: Research, Theory \& Practice, 17(1) 44-63. DOI: 10.1177/1521025115571102

Miller, J. W., \& Lesik, S. S. (2014). College persistence over time and participation in a first-year seminar. Journal of College Student Retention: Research, Theory \& Practice, 16(3), 373-390. DOI: 10.2190/CS.16.3.d

Mills, M. T. (2010). Tools of engagement: Success course influence on student engagement. Journal of the First-Year Experience \& Students in Transition, 22(2), 9-32. Retrieved from https://eric.ed.gov/?id=EJ906628

National Resource Center for The First-Year Experience and Students in Transition (2013). 20122013 National survey of first-year seminars. The University of South Carolina. Retrieved from http://sc.edu/fye/research/surveys/survey_instruments/pdf/Executive_Summaries_2013_ National_Survey_FirstYearSeminars.pdf

Oblinger, D. (2003). Boomers, gen-xers, millennials: Understanding the new students. EDUCAUSE Review, 38(4), 37-47. Retrieved from: https://www.educause.edu/ir/library/pdf/erm0342.pdf

Padgett, R. D., Keup, J. R., \& Pascarella, E. T. (2013). The impact of first-year seminars on college students' life-long learning orientations. Journal of Student Affairs Research and Practice, 50(2), 133-151. DOI:10.1515/jsarp-2013-0011

Pardue, K.T. \& Morgan, P. (2008). Millennials considered: A new generation, new approaches, and implications for nursing education. Nursing Education Perspectives, 29(2), 74-79. Retrieved from: https://www.ncbi.nlm.nih.gov/pubmed/18459621

Rath, S. (2008). Converting distress into stress. Social Science International, 24(1), 98-103. Retrieved from PsycINFO database.

Reynolds, J. R., \& and Baird, C. L. (2010). Is there a downside to shooting for the stars? Unrealized educational expectations and symptoms of depression. American Sociological Review, 75(1) 151172. DOI: $10.1177 / 0003122409357064$

Journal of the Scholarship of Teaching and Learning, Vol. 20, No. 2, October 2020. josotl.indiana.edu 
Rickes, P.C. (2009). Make way for Millennials! How today's students are shaping higher education space. Planning for Higher Education, 37(2), 7-17. Retrieved from: https://eric.ed.gov/?id=EJ831268

Shaw, S. \& Fairhurst, D. (2008). Engaging a new generation of graduates. Education \& Training, 50(5), 366-378. Retrieved from: https://eric.ed.gov/?id=EJ801305

Sternberg, J. R. (2012) It's the end of the university as we know it (and I feel fine): The Generation Y student in higher education discourse. Higher Education Research \& Development, 31(4), 571 583, DOI: $10.1080 / 07294360.2011 .559193$

Strapp, C. M., \& Farr, R. J. (2010). To get involved or not: The relation among extracurricular involvement, satisfaction, and academic achievement. Teaching of Psychology, 37, 50-54. DOI: 10.1080/00986280903425870

Stupinsky, R. H., Renaud, R. D., Perry, R. P. Ruthig, J. C., \& Haynes, T. L. (2007). Comparing selfesteem and perceived control as predictors of first-year college students' academic achievement. Social Psychology of Education, 10(3), 303-330. DOI: 10.1007/s11218-007-9020-4

Teodorescu, R. E., Bennhold, C., Feldman, G. \& Medsker, L. (2014). Curricular reforms that improve students' attitudes and problem-solving performance. European Journal of Physics Education, 5(1), 15-44. Retrieved from https:// files.eric.ed.gov/fulltext/EJ1051508.pdf

That, K., \& Must O. (2013) Comparability of educational achievement and learning attitudes across nations, Educational Research and Evaluation, 19(1), 19-38, DOI: 10.1080/13803611.2012.750443

Thompson, D. E., Orr, B., Thompson, C., \& Kenda, G. (2007). Examining students' perceptions of their first-semester experience at a major land-grand institution. College Student Journal, 41(3), 640-648. Retrieved from https://eric.ed.gov/?id=EJ777970

Tuckman, B. W. \& Kennedy, G. J. (2011). Teaching learning strategies to increase success of firstterm college students. The Journal of Experimental Education, 79, 478-504. DOI: 10.1080/00220973.2010.512318

Turner, J. E., \& Husman, J. (2008). Emotional and cognitive self-regulation following academic shame. Journal of Advanced Academics, 20(1), 138-173. Retrieved from https:// files.eric.ed.gov/fulltext/EJ835871.pdf

Twenge, J.M., Zhang, L. \& Im, C. (2004). It's beyond my control: a cross-temporal meta-analysis of increasing externality in locus of control, 1960-2002. Personality and Social Psychology Review, 8(3), 308-19. DOI: 10.1207/s15327957pspr0803_5

Vilorio, D. (2011). Focused jobseeking: A measured approach for looking for work. Occupational Outlook Quarterly, 55(1), 2-11. Retrieved from www.sciepub.com/reference/41836

Wolff, H. G., \& Moser, K. (2009). Effects of networking on career success: A Longitudinal study. Journal of Applied Psychology, 94(1), 196-206. DOI: 10.1037/a0013350 